African Crop Science Journal by African Crop Science Society is licensed under a Creative Commons Attribution 3.0 Uganda License. Based on a work at www.ajol.info/ and www.bioline.org.br/cs DOI: https://dx.doi.org/10.4314/acsj.v29i1.3

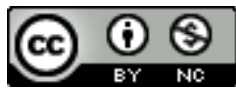

\title{
EVALUATION OF TIGERNUT ACCESSIONS IN GHANA FOR PROXIMATE AND MINERAL COMPOSITION
}

\author{
E.F. DONKOR, D. NYADANU ${ }^{1}$ and H.K. DAPAAH
}

University of Energy and Natural Resources, Department of Horticulture and Crop Production, Sunyani, Ghana

${ }^{1}$ Cocoa Research Institute of Ghana, Tafo, Koforidua, Eastern Region, Ghana

Corresponding author: esther.donkor@uenr.edu.gh

(Received 8 August 2020; accepted 5 February 2021)

\begin{abstract}
Tigernut (Cyperus esculentus L.) is a nutritious, yet underutilised crop in Ghana. The objective of this study was to characterise Ghanaian tigernut accessions for proximate and mineral composition, as a guide for breeders for varietal development. Field and laboratory studies were conducted on 24 tigernut accessions from major growing areas of Ghana. The accessions were cultivated during the minor the growing season (September - November), at the Multipurpose Nursery of the University of Education, Winneba, Asante Mampong in Ghana. The nuts were analysed for proximate (carbohydrate, energy, moisture, ether extract, crude fiber, crude protein and ash) and mineral (potassium, phosphorus and calcium) composition. There were significant $(\mathrm{P}<0.05)$ differences among accessions for all traits studied. Accessions were clustered in a dendrogram by colour and geographical origin and $\mathrm{PC} 1$ and PC2 explained more than $80 \%$ of the total variations among the accessions, with carbohydrate and energy being the major contributors to the total variation. Accessions DY, BKB, KAB, TPY, CCY, WY2 and WY1, which recorded high levels of proximate and mineral compositions, may be considered for breeding programmes to provide high nutrient varieties of tigernut in Ghana.
\end{abstract}

Key Words: Carbohydrate, cluster analysis, Cyperus esculentus

\section{RÉSUMÉ}

Le Tigernut (Cyperus esculentus L.) est une culture nutritive mais sous-utilisée au Ghana. L'objectif de cette étude était de caractériser les accessions de souchet Ghanéen pour leur composition immédiate et minérale, comme un guide pour les sélectionneurs pour le développement variétal. Des études sur le terrain et en laboratoire ont été menées sur 24 accessions de souchet provenant des principales zones de culture du Ghana. Les accessions ont été cultivées pendant la petite saison de croissance (Septembre - Novembre), à la pépinière polyvalente de l'Université de l'éducation, Winneba, Asante Mampong au Ghana. Les noix ont été analysées pour leur composition proche (glucides, énergie, humidité, extrait d'éther, fibres brutes, protéines brutes et cendres) et composition minérale (potassium, phosphore et calcium). Il y avait des différences significatives $(\mathrm{P}<0,05)$ entre les accessions pour tous 
les caractères étudiés. Les accessions ont été regroupées dans un dendrogramme par couleur et origine géographique et $\mathrm{PC} 1$ et $\mathrm{PC} 2$ expliquaient plus de $80 \%$ des variations totales entre les accessions, les glucides et l'énergie étant les principaux contributeurs à la variation totale. Les accessions DY, $\mathrm{BKB}, \mathrm{KAB}, \mathrm{TPY}, \mathrm{CCY}, \mathrm{WY} 2$ et WY1, qui ont enregistré des niveaux élevés de composition proximale et minérale, peuvent être envisagées pour des programmes de sélection afin de fournir des variétés riches en nutriments de tigernut au Ghana.

Mots Clés: Glucides, l'analyse par grappes, Cyperus esculentus

\section{INTRODUCTION}

Tigernut (Cyperus esculentus $\mathrm{L}$ ) is one of the underutilised crops in Ghana, which is associated with dismal levels of research. It belongs to the cyperacea family and produces edible, highly nutritious and medicinal tubers (Cortes et al., 2005). Typically, $100 \mathrm{~g}$ of the nuts contain $386 \mathrm{kcal}$ (1635 kj) of energy, $7 \%$ proteins, $26 \%$ fats (oils), $31 \%$ starch, $21 \%$ glucose and $26 \%$ fibre (Sanful, 2009). It is also rich in vitamins A, B1, D2 and E; minerals: calcium, magnesium, sodium, potassium, copper and iron; and beneficial enzymes (Ayeh-Kumi et al 2014). Besides, it is rich in myristic acids, linoleic acid and oleic acid which are said to be cardiac preventive (Esteshola and Oraedu, 1996).

In order to alleviate the problem of malnutrition and food shortage, the development and use of these tubers is advocated (Bhat and Karim, 2009), and tigernut is one of the targeted crops for the alleviation of malnutrition in Ghana (Asare et al 2020). In Ghana, the available tigernut accessions have not been evaluated for nutritional composition to facilitate their proper use by breeding plant programmes. The objective of the study was to characterise Ghanaian tigernut accessions for proximate and mineral composition, as a guide for breeders for varietal development.

\section{MATERIALS AND METHODS}

Study area. The study was conducted at the Multipurpose Nursery of the College of Agriculture, University of Education, Winneba
Mampong Ashanti in Ghana. MampongAshanti is located on longitude $1.30^{\circ} \mathrm{W}$ and latitude $7.30^{\circ} \mathrm{N}$, at an altitude of $395 \mathrm{~m}$ above sea level. The area has mean annual rainfall of $1270 \mathrm{~mm}$, distributed in two seasons (March - July and September-November). Mean daily temperature is $27^{\circ} \mathrm{C}$ (Metrological Service, Mampong, 2010, www.statsgha.gov.gh).

Germplasm collection. Twenty-four accessions of tigernut were collected from six major tigernut growing regions in Ghana, namely Eastern region (Asukese Donkokrom, Nkwakwa), Volta region (Krachi), Upper East region (Bawku), Upper West region (Wa), Central region (Kasoa, Badwiase, Gomoa Feteh, Twifo Praso) and Bono East region (Techiman) ( Table 1).

The accessions collected were kept in polyethylene bags and tagged with the names of towns where they were collected. The accessions were then named using the first letters of the towns where they were collected; and the colour of the nuts. Numbers were used to differentiate accessions from the same town, which had the same colour, for example WY1 meaning Wa Yellow, first accession.

Germplasm evaluation. The accessions were planted in a randomised block design (RCBD) with five replications, in plastic buckets. The volume of the buckets used was 1.22 litres each and was filled with sterilised sandy loam soil. Each bucket contained five stands of tigernut per genotype.

The stands were arranged $5 \mathrm{~cm}$ within rows and $5 \mathrm{~cm}$ between rows. The edible nuts were used for the study, and were raised under 
TABLE 1. Source and colour of tigernut accessions collected from different part of Ghana for the study

\begin{tabular}{llll}
\hline Accessions & Collection place/area & Region & Colour \\
\hline ADS & Asukese Donkorkrom & Eastern & Yellow \\
KB & Krachi & Volta & Black \\
KY & Krachi & Volta & Yellow \\
KAB & Kwanyako & Central & Black \\
KAY & Kwanyako & Central & Yellow \\
WY 1 & Wa & Upper West & Yellow \\
DY & Bodwiase & Central & Yellow \\
BB & Bawku & Upper East & Black \\
BY & Bawku & Upper East & Yellow \\
TY & Techiman & Brong Ahafo & Yellow \\
BLB & Badwiase & Central & Black \\
BLY & Badwiase & Central & Yellow \\
CCB & Kasoa & Central & Black \\
CCY & Kasoa & Central & Yellow \\
AY & Nkwakwa & Eastern & Yellow \\
TPB & Twifo Praso & Central & Black \\
TPY & Twifo Praso & Central & Yellow \\
BKB & Badwiase & Central & Black \\
WY2 & Wa & Upper West & Yellow \\
BKY & Badwiase & Central & Yellow \\
WB & Wa & Upper West & Black \\
GFB & Gomoa Fetteh & Central & Black \\
GFY & Gomoa Fetteh & Central & Yellow \\
ADL & Asukese donkokrom & Eastern & Yellow \\
\hline
\end{tabular}

ADS = Asukese Donkorkrom Short, KB = Krachi Black), KY = Krachi Yellow, KAB = Kwanyaako Asamoahkrom Black, KAY = Kwanyaako Asamoahkrom Yellow, WY1 = Waa Yellow 1, DY = Danso Yellow, BB = Bawku Black, BY = Bawku Yellow, TY = Techiman Yellow, BLB = Badwiase Local Black, $\mathrm{BLY}=$ Badwiase Local Yellow, $\mathrm{CCB}=$ Cape Coast Black, $\mathrm{CCY}=$ Cape Coast Yellow, $\mathrm{AY}=$ Aduamoah Yellow, TPB = Twifo Praso Black, TPY = Twifo Praso Yellow, WY2 = Waa Yellow 2, BKB = Bawjiase Kwahu Black, BKY = Bawjiase Kwahu Yellow, WB = Waa Black, GFB = Gommoa Fetteh Black, GFY = Gommoa Fetteh Yellow, ADL = Asukese Donkokrom Short

irrigation and manual weeding. One hundred grammes of nuts of each accession were washed with tap water to remove sand particles, before the nuts were air dried and put into transparent polythene bags before analysis.

Proximate analysis. The air-dried nut samples were analysed for moisture, ash and crude fibre in triplicates; using the Standard
Protocols of Association of Official Chemist (AOAC, 1998). Nitrogen was determined by the micro-Kjedahl method, described by Pearson (1976); and converted into protein by multiplying with a factor of 6.25. Carbohydrate was determined by the difference method (Equation 1).

$\%$ Carbohydrates $=100-\%$ moisture $-\%$ protein $-\%$ fat $-\%$ ash ........... Equation 1 
The energy content was determined by Equation 2:

Energy $=[(3.5 \mathrm{X} \% \mathrm{CP})+(8.5 \mathrm{X} \mathrm{EE})+(3.5 \mathrm{X}$ $\mathrm{NFE})] / 10$ Equation 2

Where:

$\mathrm{CP}=$ Crude Protein, $\mathrm{EE}=$ Ether Extract and $\mathrm{NFE}=$ Nitrogen Free Extract

Mineral analysis. The procedures described by AOAC (1998) were used for the mineral analysis. By these procedures, ash was digested with $3 \mathrm{ml}$ of $\mathrm{HCl}$ and made up to the mark in a $100 \mathrm{ml}$ standard flask with $0.36 \mathrm{HCl}$, before calcium, atomic absorption spectrometer (AAS). Phosphorus was determined by the spectrophotometric method and potassium by the flame photometer method.

Statistical analysis. The data collected were subjected to analysis of variance (ANOVA) using the GenStat statistical software, version 11.1 (GenStat, 2008). Dissimilarity matrix, based on Euclidean distance, was estimated using the same software. The scores of the dissimilarity matrix were used to perform a hierarchical cluster analysis (Ward, 1963). Principal Component Analysis (PCA) based on traits studied was performed to understand the relative contribution of the different traits to the total variation in tigernut. A biplot was drawn to demonstrate the relationship between the accessions and the traits, using the Eigen values associated with the components.

\section{RESULTS}

Proximate and mineral analysis. There were significant $(\mathrm{P}<0.05)$ difference among the 24 accessions of tigernut for proximate and mineral compositions (Table 2). Nitrogen Free Extracts (NFE) ranged from 3.84 to $37.33 \%$ for DY and BKB, respectively; while the energy content varied from $9.19 \%$ for accession WY to 25.05 for accession BLB. Overall, accession WY2 contained the highest amount of crude fiber $(24.35 \%)$; while accession TPB contained the least amount $(9.08 \%)$.

Ash content ranged from 1.33 to $11.30 \%$, with accessions WY1 recording the highest and GFB the least amount (Table 2). Among the accessions studied, DY had the highest amount of crude protein; while accession BY had the least amount. Accession KAB recorded the highest amount of ether extract; while TPY recorded the least.

For moisture content, the range varied from $34.50 \%$ for BY to $49.50 \%$ for ADL. It was further observed that BKY had the highest amount of potassium (3.53 mg $\left.100 \mathrm{~g}^{-1}\right)$, with ADS having the least $\left(1.28 \mathrm{mg} 100 \mathrm{~g}^{-1}\right)$. Phosphorus content ranged from $0.25 \mathrm{mg} 100$ $\mathrm{g}^{-1}$ for ADS to $1.19 \mathrm{mg} 100 \mathrm{~g}^{-1}$ for CCY. Calcium also varied from $0.12 \mathrm{mg} 100 \mathrm{~g}^{-1}$ in accession GFY to $0.40 \mathrm{mg} 100 \mathrm{~g}^{-1}$ in accession DY.

Cluster analysis. Proximate and mineral data were used to estimate Euclidean distances between the tigernut genotypes, and a dendrogram was constructed (Fig. 1). The analysis distinguished the 24 accessions into seven clusters, at $85 \%$ similarity index. Table 3 shows the means of proximate and mineral composition for the seven clusters; while Table 4 shows the clusters, number of accessions in each cluster and the traits that define each cluster based on the proximate and nutritional composition. Cluster I contained the highest number of accessions (10), which were characterised by high crude protein and crude fiber content. Cluster II consisted of 5 accessions characterised by high crude protein, crude fiber ash, moisture, calcium, potassium and phosphorus.

High crude fiber, ether extract, ash and energy characterised cluster III; which was also characterised by high moisture content, calcium, potassium and phosphorus. Clusters IV, VI and VII consisted of one accession 
TABLE 2. Data for proximate and mineral composition of the tigernut accessions evaluated In Ghana

\begin{tabular}{|c|c|c|c|c|c|c|c|c|c|c|}
\hline Accessions & $\mathrm{K}$ mg $100 \mathrm{~g}^{-1}$ & P mg $100 \mathrm{~g}^{-1}$ & $\% \mathrm{CF}$ & $\% \mathrm{ASH}$ & Ca mg $100 \mathrm{~g}^{-1}$ & $\% \mathrm{CP}$ & $\% \mathrm{FAT}$ & $\%$ Moisture & \%Energy & $\% \mathrm{NFE}$ \\
\hline ADS & $1.28 \pm 0.01$ & $0.24 \pm 0.03$ & $17.63 \pm 0.06$ & $3.33 \pm 0.33$ & $0.20 \pm 0.06$ & $5.56 \pm 0.08$ & $9.67 \pm 0.33$ & $40.17 \pm 0.16$ & $18.44 \pm 0.31$ & $23.63 \pm 0.14$ \\
\hline $\mathrm{KB}$ & $2.27 \pm 0.03$ & $0.59 \pm 0.06$ & $15.79 \pm 0.08$ & $3.50 \pm 0.50$ & $0.31 \pm 0.06$ & $4.80 \pm 0.05$ & $9.33 \pm 0.16$ & $43.33 \pm 0.16$ & $17.75 \pm 0.16$ & $23.25 \pm 0.77$ \\
\hline KY & $2.16 \pm 0.01$ & $0.54 \pm 0.01$ & $20.22 \pm 0.05$ & $6.33 \pm 0.33$ & $0.20 \pm 0.06$ & $4.83 \pm 0.06$ & $11.83 \pm 0.16$ & $45.33 \pm 0.16$ & $15.76 \pm 0.14$ & $11.45 \pm 0.05$ \\
\hline KAB & $1.89 \pm 0.06$ & $0.35 \pm 0.06$ & $12.97 \pm 0.07$ & $2.16 \pm 0.16$ & $0.20 \pm 0.01$ & $4.86 \pm 0.03$ & $19.33 \pm 0.66$ & $41.17 \pm 0.16$ & $24.96 \pm 0.37$ & $19.50 \pm 0.56$ \\
\hline KAY & $2.20 \pm 0.03$ & $0.41 \pm 0.06$ & $10.72 \pm 0.06$ & $2.33 \pm 0.33$ & $0.20 \pm 0.06$ & $5.53 \pm 0.06$ & $15.17 \pm 0.16$ & $42.33 \pm 0.16$ & $23.20 \pm 0.18$ & $23.92 \pm 0.49$ \\
\hline WY & $3.38 \pm 0.06$ & $0.85 \pm 0.03$ & $11.63 \pm 0.02$ & $11.33 \pm 0.33$ & $0.35 \pm 0.06$ & $5.03 \pm 0.03$ & $8.33 \pm 0.16$ & $54.17 \pm 0.16$ & $12.17 \pm 0.14$ & $9.50 \pm 0.61$ \\
\hline DY & $3.19 \pm 0.01$ & $0.83 \pm 0.03$ & $20.42 \pm 0.02$ & $6.16 \pm 0.16$ & $0.40 \pm 0.06$ & $5.73 \pm 0.03$ & $15.50 \pm 0.28$ & $48.33 \pm 0.33$ & $16.53 \pm 0.22$ & $3.84 \pm 0.59$ \\
\hline $\mathrm{BB}$ & $2.01 \pm 0.08$ & $0.44 \pm 0.06$ & $15.92 \pm 0.04$ & $6.50 \pm 0.28$ & $0.26 \pm 0.03$ & $5.06 \pm 0.06$ & $15.50 \pm 0.28$ & $37.17 \pm 0.16$ & $21.90 \pm 0.09$ & $19.85 \pm 0.49$ \\
\hline BY & $2.15 \pm 0.06$ & $0.45 \pm 0.01$ & $18.00 \pm 0.04$ & $5.16 \pm 0.16$ & $0.23 \pm 0.06$ & $4.16 \pm 0.03$ & $13.17 \pm 0.16$ & $34.50 \pm 0.28$ & $21.40 \pm 0.18$ & $25.00 \pm 0.41$ \\
\hline BY & $2.15 \pm 0.06$ & $0.45 \pm 0.01$ & $18.00 \pm 0.04$ & $5.16 \pm 0.16$ & $0.23 \pm 0.06$ & $4.16 \pm 0.03$ & $13.17 \pm 0.16$ & $34.50 \pm 0.28$ & $21.40 \pm 0.18$ & $25.00 \pm 0.41$ \\
\hline TY & $3.52 \pm 0.01$ & $0.96 \pm 0.06$ & $13.28 \pm 0.02$ & $5.83 \pm 0.44$ & $0.20 \pm 0.01$ & $4.36 \pm 0.03$ & $6.33 \pm 0.16$ & $50.50 \pm 0.28$ & $13.80 \pm 0.29$ & $19.69 \pm 0.60$ \\
\hline BLB & $2.22 \pm 0.03$ & $0.42 \pm 0.06$ & $15.49 \pm 0.02$ & $3.16 \pm 0.16$ & $0.16 \pm 0.06$ & $4.73 \pm 0.06$ & $19.17 \pm 0.16$ & $37.17 \pm 0.16$ & $25.05 \pm 0.18$ & $20.28 \pm 0.24$ \\
\hline BLY & $2.68 \pm 0.06$ & $0.76 \pm 0.01$ & $14.30 \pm 0.05$ & $6.16 \pm 0.16$ & $0.19 \pm 0.06$ & $5.16 \pm 0.03$ & $9.00 \pm 0.28$ & $38.33 \pm 0.33$ & $18.92 \pm 0.22$ & $27.03 \pm 0.55$ \\
\hline $\mathrm{CCB}$ & $2.90 \pm 0.01$ & $0.82 \pm 0.03$ & $14.84 \pm 0.02$ & $4.83 \pm 0.44$ & $0.12 \pm 0.06$ & $5.26 \pm 0.03$ & $18.17 \pm 0.16$ & $38.50 \pm 0.28$ & $23.72 \pm 0.28$ & $18.40 \pm 0.48$ \\
\hline $\mathrm{CCY}$ & $3.42 \pm 0.23$ & $1.19 \pm 0.06$ & $18.18 \pm 0.01$ & $1.50 \pm 0.28$ & $0.12 \pm 0.01$ & $5.56 \pm 0.03$ & $11.33 \pm 0.16$ & $42.17 \pm 0.16$ & $19.02 \pm 0.13$ & $21.25 \pm 0.02$ \\
\hline $\mathrm{AY}$ & $3.02 \pm 0.03$ & $0.84 \pm 0.01$ & $10.57 \pm 0.03$ & $2.50 \pm 0.28$ & $0.34 \pm 0.03$ & $4.83 \pm 0.06$ & $5.17 \pm 0.16$ & $52.17 \pm 0.16$ & $14.75 \pm 0.20$ & $24.76 \pm 0.15$ \\
\hline TPB & $3.40 \pm 0.03$ & $1.07 \pm 0.06$ & $9.09 \pm 0.01$ & $8.50 \pm 0.28$ & $0.23 \pm 0.06$ & $4.56 \pm 0.03$ & $9.33 \pm 0.16$ & $38.50 \pm 0.28$ & $20.04 \pm 0.13$ & $30.01 \pm 0.33$ \\
\hline TPY & $3.81 \pm 0.01$ & $1.08 \pm 0.01$ & $13.68 \pm 0.02$ & $2.33 \pm 0.33$ & $0.16 \pm 0.06$ & $5.26 \pm 0.03$ & $3.17 \pm 0.16$ & $44.33 \pm 0.16$ & $15.46 \pm 0.08$ & $31.22 \pm 0.57$ \\
\hline WY2 & $3.29 \pm 0.03$ & $0.75 \pm 0.06$ & $24.35 \pm 0.07$ & $6.16 \pm 0.16$ & $0.12 \pm 0.01$ & $5.13 \pm 0.08$ & $4.33 \pm 0.33$ & $49.50 \pm 0.28$ & $9.16 \pm 0.30$ & $10.51 \pm 0.27$ \\
\hline BKB & $2.75 \pm 0.06$ & $0.53 \pm 0.06$ & $11.97 \pm 0.02$ & $1.16 \pm 0.16$ & $0.35 \pm 0.06$ & $5.20 \pm 0.05$ & $7.50 \pm 0.28$ & $36.83 \pm 0.44$ & $21.26 \pm 0.06$ & $37.33 \pm 0.84$ \\
\hline BKY & $3.52 \pm 0.06$ & $0.89 \pm 0.03$ & $9.37 \pm 0.07$ & $2.83 \pm 0.44$ & $0.20 \pm 0.06$ & $5.06 \pm 0.06$ & $5.17 \pm 0.16$ & $44.50 \pm 0.28$ & $17.74 \pm 0.31$ & $33.06 \pm 0.53$ \\
\hline WB & $3.00 \pm 0.03$ & $0.51 \pm 0.01$ & $12.35 \pm 0.01$ & $2.16 \pm 0.16$ & $0.18 \pm 0.06$ & $4.86 \pm 0.03$ & $13.33 \pm 0.16$ & $39.67 \pm 0.44$ & $22.70 \pm 0.18$ & $27.61 \pm 0.39$ \\
\hline GFB & $3.45 \pm 0.03$ & $0.75 \pm 0.03$ & $11.70 \pm 0.05$ & $1.33 \pm 0.16$ & $0.20 \pm 0.06$ & $4.83 \pm 0.06$ & $11.50 \pm 0.28$ & $35.50 \pm 0.28$ & $23.76 \pm 0.12$ & $35.13 \pm 0.63$ \\
\hline GFY & $3.14 \pm 0.03$ & $0.56 \pm 0.03$ & $12.50 \pm 0.08$ & $1.33 \pm 0.33$ & $0.12 \pm 0.01$ & $5.53 \pm 0.03$ & $3.33 \pm 0.33$ & $46.33 \pm 0.16$ & $15.61 \pm 0.05$ & $30.97 \pm 0.78$ \\
\hline ADL & $3.15 \pm 0.06$ & $0.57 \pm 0.01$ & $10.89 \pm 0.01$ & $2.50 \pm 0.28$ & $0.16 \pm 0.06$ & $4.86 \pm 0.0$ & $5.00 \pm 0.28$ & $46.50 \pm 0.28$ & $16.54 \pm 0.08$ & $30.25 \pm 0.75$ \\
\hline $\operatorname{LSD}(5 \%)$ & 0.15 & 0.02 & 0.060 & 0.62 & 0.02 & 0.14 & 0.75 & 0.69 & 0.49 & 1.24 \\
\hline CV (\%) & 3.10 & 1.30 & 0.30 & 9.20 & 5.40 & 1.70 & 4.40 & 1.0 & 1.60 & 3.30 \\
\hline
\end{tabular}

ADS = Asukese Donkorkrom Short, KB = Krachi Black), KY = Krachi Yellow, KAB = Kwanyaako Asamoahkrom Black, KAY = Kwanyaako Asamoahkrom Yellow, WY = Waa Yellow, DY = Danso Yellow, BB = Bawku Black, BY = Bawku Yellow, TY = Techiman Yellow, BLB = Badwiase Local Black, BLY = Badwiase Local Yellow, CCB $=$ Cape Coast Black, CCY = Cape Coast Yellow, AY = Aduamoah Yellow, TPB = Twifo Praso Black, TPY = Twifo Praso Yellow, WY2 = Waa Yellow 2, BKB = Bawjiase Kwahu Black, BKY = Bawjiase Kwahu Yellow, WB = Waa Black, GFB = Gommoa Fetteh Black, GFY = Gommoa Fetteh Yellow, ADL = Asukese Donkokrom Short 


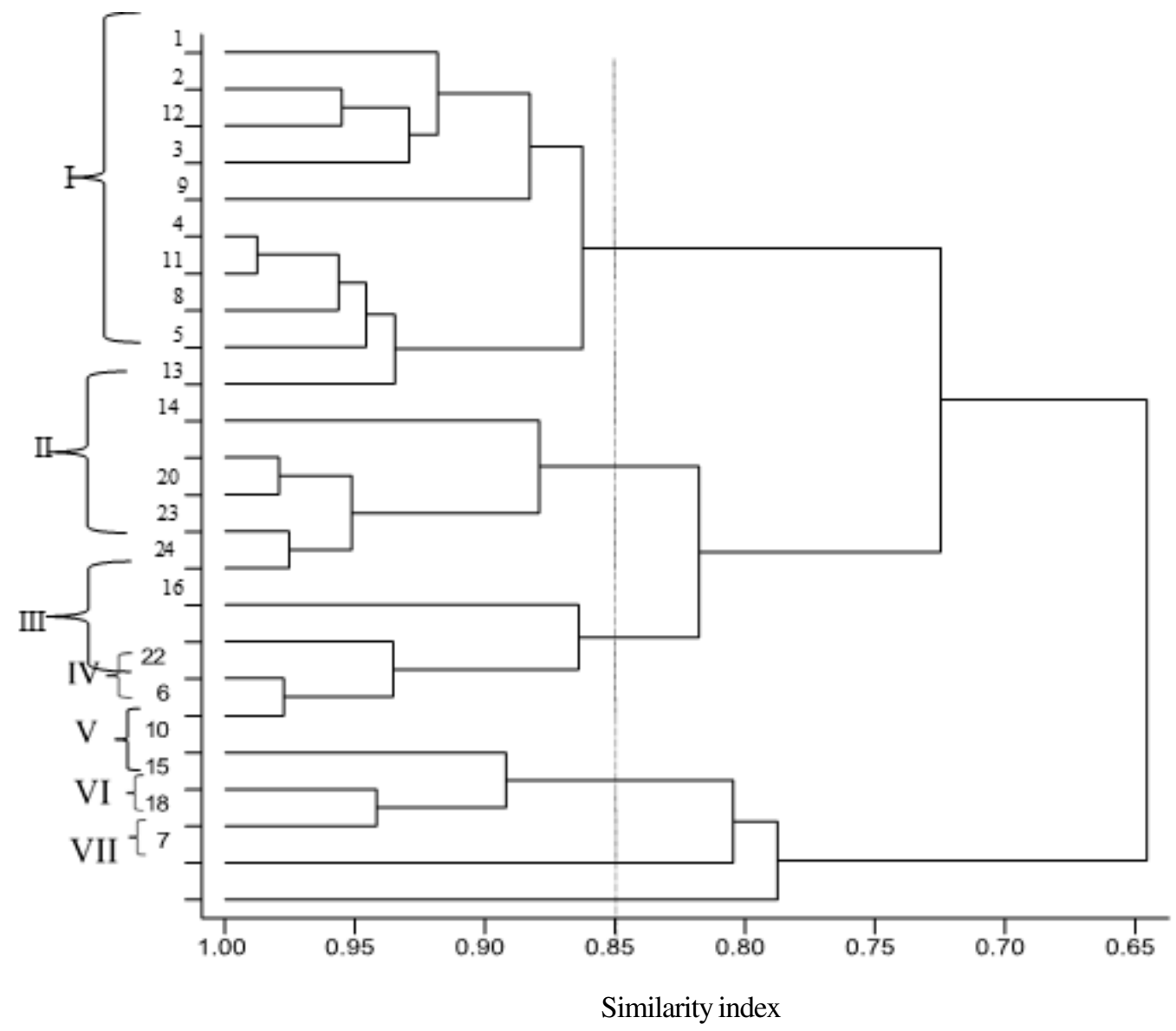

Figure 1. Dendrogram showing the diversity in proximate and mineral composition among the twentyfour Ghanaian tigernut accessions used in the study.

each, WY1, BKB and DY, respectively. Cluster 4 was characterised by high ether extract, ash, NFE and energy content; while clusters VI and VII were characterised by high NFE, energy, phosphorus and potassium.

Principal component analysis. Variations among the accessions for the proximate and mineral contents were also assessed using Principal Components Analysis (PCA). The first five principal components (PC) extracted gave an accumulation of over $90 \%$ of the total variation noted among the tigernut accessions, for the proximate and mineral composition (Tables 5 and 6). Of these, up to $33.4 \%$ of the total variation was explained by $\mathrm{PC} 1$ alone, with Eigen value of 3.33. Moisture, energy, phosphorus and potassium contents had positive and high weightings for the $\mathrm{PC} 1$ axis. PC2 with Eigen value of 2.39 explained up to $24 \%$ of the total variation, with ether extract, crude fiber, and ash having high and positive weightings. PC3, PC4 and PC5 explained $13.4,10.4$ and $9.1 \%$, respectively, of the total variation with the Eigen values 1.33, 1.04 and 0.91 , respectively. The distribution of the accessions in all quarters of the biplot showed the wide diversity among the accessions for the proximate and mineral components (Fig. 2). 
TABLE 3. Proximate and mineral composition for the seven clusters of twenty-four tigernut accessions in Ghana

\begin{tabular}{lrrrrrrrr}
\hline Variable & \multicolumn{7}{c}{ Clusters } \\
\cline { 2 - 8 } & \multicolumn{1}{c}{ I } & \multicolumn{1}{c}{ II } & III & IV & V & VI & VII & Grand \\
\hline \%CP & 5.311 & 5.183 & 4.8200 & 5.0334 & 4.6000 & 5.1834 & 5.0167 & 5.0361 \\
\%CF & 17.200 & 19.156 & 15.441 & 11.614 & 11.926 & 11.609 & 11.833 & 14.410 \\
\%Fat & 10.111 & 9.999 & 17.066 & 11.708 & 5.7500 & 4.1668 & 9.5000 & 10.402 \\
\%Ash & 2.777 & 7.500 & 4.3668 & 4.7918 & 4.1665 & 2.2498 & 1.2500 & 4.1319 \\
\%Moisture & 41.889 & 49.333 & 37.700 & 39.708 & 51.333 & 45.416 & 36.166 & 42.791 \\
\%NFE & 22.711 & 8.826 & 20.605 & 27.144 & 22.223 & 31.374 & 36.233 & 23.227 \\
\%Energy & 18.402 & 13.403 & 23.405 & 21.214 & 14.275 & 16.337 & 22.512 & 18.734 \\
Ca(mg 100 g-1) & 0.213 & 0.271 & 0.198 & 0.205 & 0.273 & 0.165 & 0.280 & 0.221 \\
P(mg 100 g g $\left.^{-1}\right)$ & 0.677 & 0.745 & 0.500 & 0.689 & 0.905 & 0.778 & 0.645 & 0.686 \\
K(mg 100 g $\left.{ }^{-1}\right)$ & 2.328 & 3.006 & 2.238 & 2.826 & 3.273 & 3.406 & 3.105 & 2.828 \\
\hline
\end{tabular}

$\mathrm{CP}=$ Crude Protein, $\mathrm{CF}=$ Crude Fibre, $\mathrm{NFE}=$ Nitrogen Free Extract, $\mathrm{Ca}=$ Calcium, $\mathrm{P}=$ Phosphorus, $\mathrm{K}$ $=$ Potassium

TABLE 4. Tigernut clusters based on proximate and nutritional composition in Ghana

\begin{tabular}{|c|c|c|c|}
\hline Cluster & $\begin{array}{l}\text { Number of } \\
\text { accessions }\end{array}$ & Accessions & Traits \\
\hline 1 & 10 & $\begin{array}{l}\text { ADS, KB, BLY, KY, BY, } \\
\text { KAB, BLB, BB, KAY, CCB }\end{array}$ & $\begin{array}{l}\text { High crude protein and crude fiber } \\
\text { content }\end{array}$ \\
\hline 2 & 5 & CCY,TPY,BKY, GFY, ADL & $\begin{array}{l}\text { High crude protein, crude fiber ash, } \\
\text { moisture, calcium, potassium } \\
\text { and phosphorus }\end{array}$ \\
\hline 3 & 4 & TPB, WY2, WB, GFB & $\begin{array}{l}\text { High crude fiber, ether extract, ash and } \\
\text { energy }\end{array}$ \\
\hline 4 & 1 & WY1 & $\begin{array}{l}\text { High ether extract, ash, NFE and energy } \\
\text { content }\end{array}$ \\
\hline 5 & 2 & TY, AY & $\begin{array}{l}\text { High moisture content, calcium, } \\
\text { potassium and phosphorus }\end{array}$ \\
\hline 6 & 1 & $\mathrm{BKB}$ & $\begin{array}{l}\text { High NFE, energy, phosphorus and } \\
\text { potassium }\end{array}$ \\
\hline 7 & 1 & DY & $\begin{array}{l}\text { High NFE, energy, phosphorus and } \\
\text { potassium }\end{array}$ \\
\hline
\end{tabular}


TABLE 5. Principal Component Analysis for the proximate and mineral composition of the twentyfour tigernut accessions $t$ in Ghana

\begin{tabular}{lccc}
\hline Principal components & Eigen value & Proportion & Cumulative \\
\hline 1 & 3.3395 & 0.334 & 0.334 \\
2 & 2.3960 & 0.240 & 0.574 \\
3 & 1.3356 & 0.134 & 0.707 \\
4 & 1.0415 & 0.104 & 0.811 \\
5 & 0.9148 & 0.091 & 0.903 \\
6 & 0.4696 & 0.047 & 0.950 \\
7 & 0.3906 & 0.039 & 0.989 \\
8 & 0.1124 & 0.011 & 1.000 \\
9 & 0.0000 & 0.000 & 1.000 \\
10 & 0.0000 & 0.000 & 1.000 \\
\hline
\end{tabular}

TABLE 6. The first five Principal Components of the proximate and mineral composition of the accessions studied

\begin{tabular}{lrrrrr}
\hline Variables & \multicolumn{1}{c}{ PC1 } & PC2 & PC3 & PC4 & PC5 \\
\hline \%Crude protein & 0.046 & 0.064 & -0.617 & -0.284 & 0.592 \\
\%fat & -0.384 & 0.309 & 0.111 & 0.275 & 0.379 \\
\%Crude fiber & 0.043 & 0.464 & -0.397 & 0.230 & -0.215 \\
\%Ash & 0.230 & 0.367 & 0.432 & 0.238 & -0.012 \\
\%Moisture & 0.460 & 0.121 & -0.041 & -0.283 & -0.029 \\
\%NFE & -0.164 & -0.587 & 0.038 & -0.143 & -0.130 \\
\%Energy & -0.500 & -0.099 & 0.118 & 0.167 & 0.309 \\
Ca (mg 100 g-1) & 0.084 & 0.184 & 0.492 & -0.559 & 0.373 \\
P(mg 100 g-1) & 0.384 & -0.206 & 0.053 & 0.445 & 0.370 \\
K (mg 100 g-1) & 0.390 & -0.324 & 0.028 & 0.309 & 0.264 \\
Eigen value & 3.3395 & 2.3960 & 1.3356 & 1.0415 & 0.9148 \\
Proportion $(\%)$ & 33.4 & 24.0 & 13.4 & 10.4 & 9.1 \\
Cumulative $(\%)$ & 33.4 & 57.4 & 70.7 & 81.1 & 90.3 \\
\hline
\end{tabular}

\section{DISCUSSION}

Proximate and mineral analysis. The significant variations among the accessions for proximate and mineral composition is an indication of the presence of a high degree of genetic variation. This implies presence of great potential of the accessions for utilisation in future breeding programmes for varietal development of nutritious tigernut in Ghana; and also for recommendation to be included in the diets of Ghanaians. The high content of the proximate and mineral content of most of the accessions studied, provides an assurance that tigernut can solve the malnutrition problems in the world, hence more research need to be done. Several authors (Ayasan et al., 2020; Madaki et al., 2018; Emurotu, 2017; Bado et al., 2015) reported significant nutritional content in tigernut.

Cluster analysis. Cluster analysis based on the proximate and mineral composition of tigernut assigned the genotypes into seven 


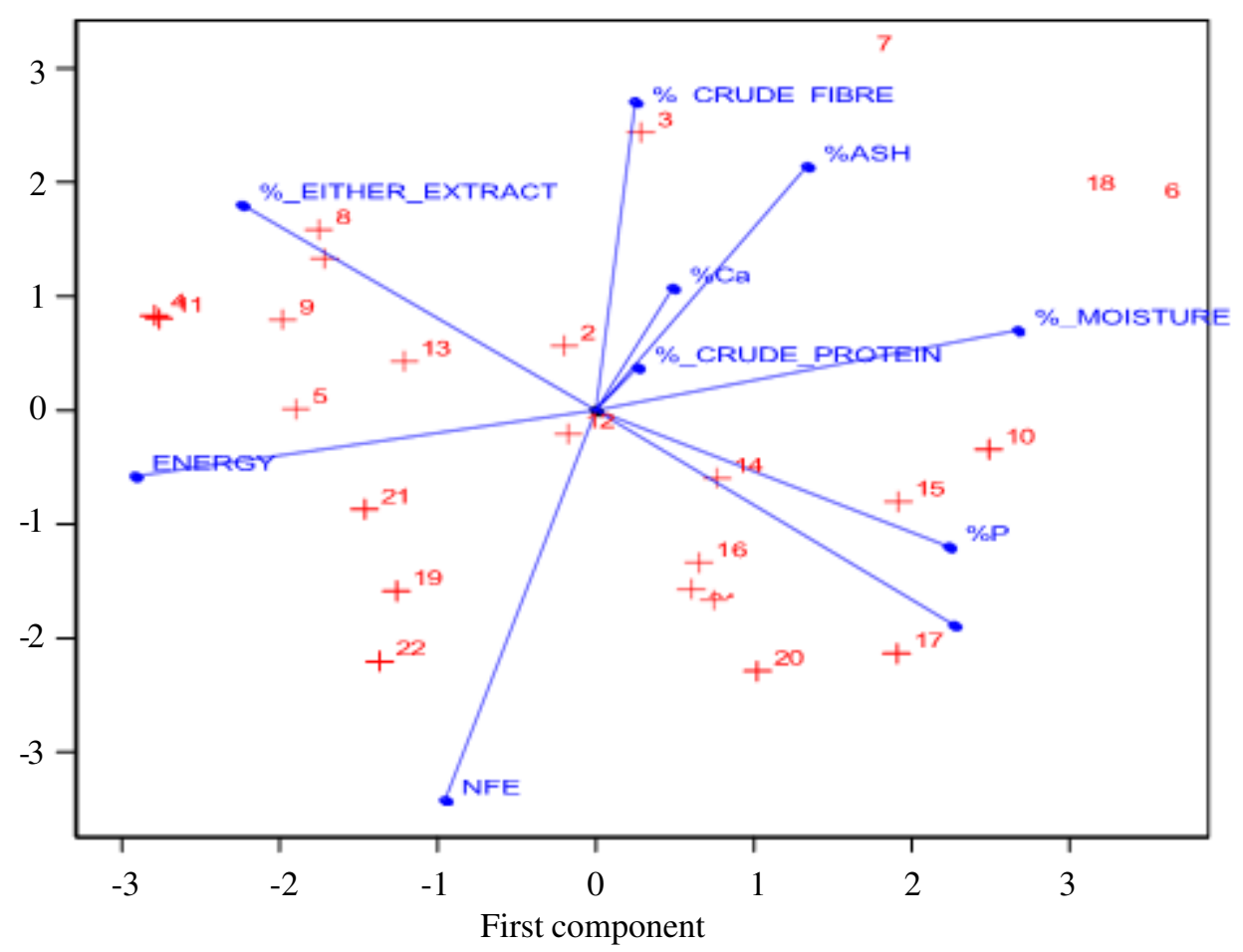

Figure 2. Biplot of the proximate and mineral composition of the twenty-four Ghanaian tigernut accessions used in the study.

different groups (Fig. 1). The groupings of the accessions from the same origin and colour into different clusters, suggests diversity among accessions within a geographical origin and among accessions beyond geographical origin. Selection and crossing of genotypes from different clusters would help in bringing together favourable genes for quality traits so as to breed highly nutritional varieties of tigernut. Selection of accessions from the same cluster for hybridisation will, therefore, not yield favourable results. Blessing et al. (2011) reported on similar results in cucurbita spp.

Principal component analysis. The fact that moisture, phosphorus, potassium and ash content were the distinguishing characters among tigernut genotypic clusters (Fig. 2), implies that focus should be put on these traits for the development of nutritious tigernut varieties in Ghana. All the above nutrients had positive eigen values, indicating that their maximum to the discrimination among the accessions. These nutrients could, therefore, be considered during nutritional improvement of tigernut through selection. Principal component analysis (PCA) helps to identify traits that have substantive and meaningful contribution towards the observed variation (Prasad et al., 2010).

\section{CONCLUSION}

The study has revealed significant diversity among the tigernut accessions for proximate and mineral composition, giving room for the selection of superior accessions to be included in varietal development programmes in Ghana. Several accessions (BKB, BLB, BKY, WY1, WY2, DY and KAB) recorded high proximate and mineral content and can, therefore, be 
considered in national and institutional breeding programmes for varietal development.

\section{REFERENCES}

Ajayi, I.A., Oderinde, R.A., Kajogbola, D.O. and Uponi, J.I. 2006. Oil content and fatty acid composition of some underutilized legumes from Nigeria. Food Chemistry 99(1):115-120.

AOAC. 1998. Official Methods of analysis of the Association of Official Analytical Chemists, 16th Edition. Gaithersburg, USA.

Asare, P.A., Kpankpari, R., Adu, M.O., Afutu, E. and Adewumi, A.S. 2020. Phenotypic characterization of tiger nuts (Cyperus esculentus 1.) from major growing areas in Ghana. The Scientific World Journal 2020. https://doi.org/10.1155/2020/7232591

Ayapan, T., Sucu, E., Ülger, I., Hýzlý, H., Çubukcu, P. and Özcan, B.D. 2020. Determination of in vitro rumen digestibility and potential feed value of tiger nut varieties. South African Journal of Animal Science 50(5).

Ayeh-Kumi, P.F., Tetteh-Quarcoo, P.B., Duedu, K.O. Obeng A. S., Addo-Osafo, K., Samuel M. and Asmah R.H. 2014. A survey of pathogens associated with Cyperus esculentus L. (tiger nuts) tubers sold in a Ghanaian city. BMC Research Notes 7:343. https://doi.org/ 10.1186/1756-0500-7-343

Bado, S., Bazongo, P., Son, G., Kyaw, M.T., Forster, B. P., Nielen, S. and Bassolé, I. H. N. 2015. Physicochemical characteristics and composition of three morphotypes of Cyperus esculentus tubers and tuber oils. Journal of Analytical Methods in Chemistry.

Bhat, R. and Karim, A.A. 2009. Exploring the nutritional potential of wild and underutilized legumes. Comprehensive Reviews in Food Science and Food Safety 8(4):305-331.

Blessing, A.C., Ifeanyi, U.M. and Chijioke, O.B. 2011. Nutritional evaluation of some Nigerian pumpkins (Cucurbita spp.). Fruit,
Vegetable and Cereal Science and Biotechnology 5(2):64-71.

Chukwuma, E.R., Obioma, N. and Christopher, O.I. 2010. The phytochemical composition and some biochemical effects of Nigerian tigernut (Cyperus esculentus L.) tuber. Pakistan Journal of Nutrition 9(7):709715.

Cortés, C., Esteve, M.J., Frýgola, A. and Torregrosa, F. 2005. Quality characteristics of horchata (a Spanish vegetable beverage) treated with pulsed electric fields during shelf-life. Food Chemistry 91(2):319-325.

Ekeanyanwu, R. C. and Ononogbu, C. I. 2010. Nutritive value of Nigerian tigernut (Cyperus esculentus L.). Agricultural Journal 5(5):297-302.

Emurotu, J.E. 2017. Comparison of the nutritive value of the yellow and brown varieties of tiger nut. IOSR Journal of Applied Chemistry 10:29-32.

Eteshola, E. and Oraedu, A.C.I. 1996. Fatty acid compositions of tigernut tubers (Cyperus esculentus L.), baobab seeds (Adansonia digitata L.), and their mixture. Journal of the American Oil Chemists' Society 73(2):255-257.

GenStat. 2008. Introduction of GenStat for windows. GenStat 11th Edition, Lawes Agricultural Trust, Rothamsted Experimental Station, UK.

Karadavut, U. and Genc, A. 2010. Relationships between chemical composition and seed yield of some lentil (Lens culinaris) cultivars. International Journal of Agriculture and Biology 12:625628.

Kimondo, J.M, Agea, J.G, Okia, C.A., Abohassan, R.A.A, Ndeunyema, E.T.N, Teklehaimanot, Z. and Mulatya, J. 2012. Physiochemical and nutritional characterization of Vitex payos (L.) Merr. (Verbenaceae): An indigenous fruit tree of Eastern Africa. Journal of Horticulture and Forestry 410:161-168.

Monago, C. and Uwakwe, A. 2009. Proximate composition and in vitro anti-sickling property of Nigeria Cyperus esculentus 
(tiger nut sedge). Trees Life Journal 4(2): Sanful, R.E. 2009. The use of tiger-nut $1-6$.

Nzikou, J.M., Mvoula-Tsiéri, M., Ndangui, C.B., Pambou-Tobi, N.P.G., Kimbonguila, A., Loumouamou, B. and Desobry, S. 2010. Characterization of seeds and oil of sesame (Sesamum indicum L.) and the kinetics of degradation of the oil during heating. Research Journal of Applied Sciences, Engineering and Technology 2(3):227-232.

Oladele, A.K. and Aina, J.O. 2007. Chemical composition and functional properties of flour produced from two varieties of tigernut (Cyperus esculentus). African Journal of Biotechnology 6(21).

Pearson, D.A. 1976. The clinical analysis of food ( $7^{\text {th }}$ Edition). Churchill Livingstone.

Prasad, K., Janve, B., Sharma, R.K. and Prasad, K.K. 2010. Compositional characterization of traditional medicinal plants: Chemo-metric approach. Archives of Applied Science Research 2(5):1-10.

Queen, J.P., Quinn, G.P. and Keough, M.J. 2002. Experimental Design and Data Analysis for Biologists. Cambridge university press.

Raubenheimer, J. 2004. An item selection procedure to maximize scale reliability and validity. South Africa Journal of Industrial Psychology 30(4):59-64.

Sánchez Zapata, E., Fernández López, J. and Angel Pérez Alvarez, J. 2012. Tiger nut (Cyperus esculentus) commercialization: health aspects, composition, properties, and food applications. Comprehensive Reviews in Food Science and Food Safety 11(4): 366-377.

(Cyperus esculentus), cow milk and their composite as substrates for yoghurt production. Pakistan Journal of Nutrition 6:755-758.

Sotelo, A., Contreras, E. and Flores, S. 1995. Nutritional value and content of antinutritional compounds and toxics in ten wild legumes of Yucatan Peninsula. Plant Foods for Human Nutrition 47(2):115-123.

Vadivel, V. and Janardhanan, K. 2005. Nutritional and anti-nutritional characteristics of seven South Indian wild legumes. Plant Foods for Human Nutrition 60(2):69-75.

Ward Jr, J.H. 1963. Hierarchical grouping to optimize an objective function. Journal of the American Statistical Association 58(301):236-244.

Woiso, D.A., Teklehaimanot, Z. and Mulatya, J. 2012 Physiochemical and nutritional characterization of Vitex payos (Lour.) Merr. (Verbenaceae): An indigenous fruit tree of Eastern Africa. Journal of Horticulture and Forestry 410:161-168.

Yerlikaya, C., Yucel, S., Erturk, Ü. and Korukluoðlu, M. 2012. Proximate composition, minerals and fatty acid composition of Juglans regia L. genotypes and cultivars grown in Turkey. Brazilian Archives of Biology and Technology 55(5): 677-683.

Zada, M., Zakir, N., Rabbani, M.A. and Shinwari, Z.K. 2013. Assessment of genetic variation in Ethiopian mustard (Brassica carinata A. Braun) germplasm using multivariate techniques. Pakistan Journal of. Botany 45(S1):583-593. 